EUROPA REGIONUM TOM XXII ROK 2015

DOI: $10.18276 / \mathrm{er} .2015 .22-12$

\author{
MARIANNA GRETA, EWA TOMCZAK-WOŹNIAK \\ Łódź
}

\title{
Wpływ euroregionalizacji na dezagraryzacje wsi i rolnictwa
}

\section{Wprowadzenie}

A uroregionalizacja jest procesem głęboko już wpisanym w europejskie procesy integracyjne. Towarzyszy im od początku powstania Wspólnot Europejskich (WE), rozwijając i ukazując coraz to nowe możliwości oddziaływania na funkcjonowanie gospodarek krajów tam gdzie funkcjonują euroregiony. Euroregionalizacja jest procesem złożonym i mającym wielokierunkowe oddziaływanie. Analiza euroregionalizacji wymaga bowiem rozpatrywanie jej w kontekście integracji, polityki regionalnej, regionów, strategii rozwojowej, czy też polityk wspólnotowych. Siła oddziaływania euroregionów idzie nie tylko w kierunku przełamywania skutków peryferyjności obszarów, ale także w kierunku pobudzania przedsiębiorczości lokalnej. Na terenach typowo rolniczych przedsiębiorczość ta to tzw. proces dezagraryzacji (Halamska 2011), czyli wieś wielofunkcyjna. Owa wielofunkcyjność, czyli dezagraryzacja, urzeczywistnia się m.in. poprzez tworzenie pozarolniczych miejsc pracy na obszarach wiejskich i zmniejszanie uzależnienia mieszkańców wsi od dochodów typowo rolniczych.

Wielofunkcyjność wiejska nie jest zupełnie nową kategorią i osiągnięciem ostatnich lat. Dawna tradycyjna wieś też była wielofunkcyjna tylko inaczej niż obecna. Proces ten przejawiał się w funkcjach produkcyjnych i socjalnych, które wykonywał wielofunkcyjny rolnik w obrębie własnego gospodarstwa. Potem te funkcje przejęły jednostki gospodarcze usytuowane poza wsią, zaś osoby bę- 
dące $\mathrm{w}$ gospodarstwach rolnych zaczęły podejmować w różnym wymiarze, zarówno czasu pracy jak i umiejętności, zajęcia poza gospodarstwem lub poza wsią. A zatem rolnik realizował swą przedsiębiorczość poza gospodarstwem rolnym.

Transformacja systemu społeczno-gospodarczego w Polsce oraz rozpoczęty proces dostosowań do członkowstwa w Unii Europejskiej (UE), a dziś już akcesja, również zmodyfikowały pojęcie wielofunkcyjności i dezagraryzacji. Aktualnie $\mathrm{w}$ ich rozumieniu pozostaje m.in. ${ }^{1}$ agroturystyka czy turystyka wiejska, chociaż nie tylko, bo np. produkty, i usługi twórczości folklorystycznej, czy twórczość kulturowa, bądź przedsiębiorczość w zakresie surowców lokalnych (żwir, drewno, glin) to również przedsiębiorczość wiejska wpisująca się w wielofunkcyjność.

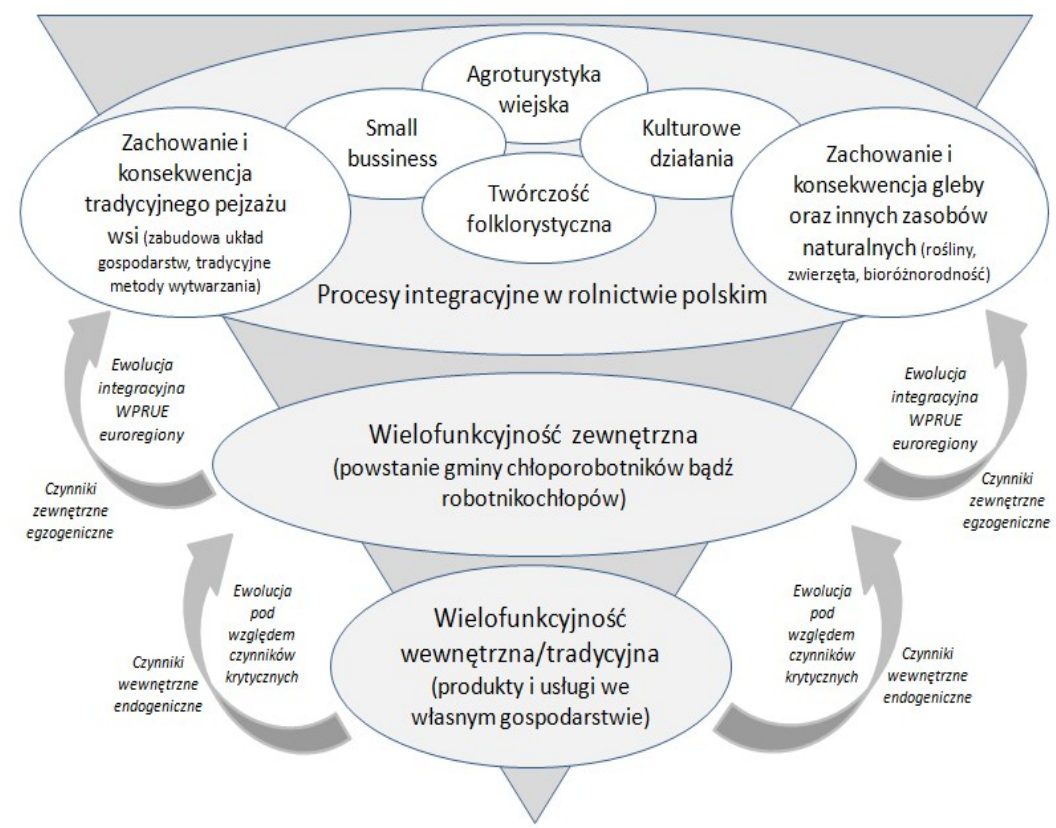

Rys. 1. Ewolucja wielofunkcyjności w rolnictwie

Źródło: opracowanie własne na podstawie wiedzy własnej o prezentowanych zagadnieniach.

1 A. Radwan, Ł. Paluch, Zróżnicowanie infrastruktury i jakości środowiska naturalnego regionów wschodniej Polski, w: K. Michałowski, Wptyw roli zrównoważonego rozwoju na politykę państwa i regionu, Problemy Regionalne i Lokalne, t. 2, Wydawnictwo WSE w Białymstoku, Białystok 2009, s. 40-45. 
Rozważania o ewolucji wielofunkcyjności wiejskiej i czynnikach ją determinujących zaprezentowano na zamieszczonym rysunku 1. Natomiast przyjęty w tytule artykułu temat pobudza do wielu pytań i dyskusji, które trudno nawet zasygnalizować $w$ wąskich ramach opracowania. W związku z tym, jako cel niżej zamieszczonych treści przyjęto przybliżenie pojęcia euroregionu oraz dokonanie analizy możliwości jego wpływu na pobudzanie wielofunkcyjności poprzez samą strukturę euro regionalną oraz „przyciąganie” szczególnych środków finansowych i realizowanie szczególnych programów operacyjnych. W przygotowaniu opracowania wykorzystano metodę badania dokumentów oraz metoda analizy piśmiennictwa i materiałów źródłowych.

\section{Krótka charakterystyka euroregionu i możliwości jego wpływu na wielofunkcyjność}

Euroregion jest zinstytucjonalizowaną współpracą transgraniczną, która łączy we współdziałania sąsiadujące ze sobą obszary graniczne państw sąsiedzkich. Jest strukturą zorganizowaną, posiada instytucje, które przyjmują na siebie obowiązki współpracy w regionie transgranicznym ${ }^{2}$. To m.in. stawia go wyżej w hierarchii organizowania współdziałania granicznego od współpracy transgranicznej będącej jedynie umową o sąsiedzkim współdziałaniu terenów i społeczności lokalnych w obszarach przy granicach państwowych.

Zbliżanie Polski do zjednoczonej Europy uruchomiło wiele różnych procesów, w tym euroregionalizację i „wybuch” euroregionów na wszystkich polskich pograniczach. Euroregiony są wciąż nie do końca odgadnionym i zbadanym fenomenem oddziaływania na obszary, które obejmują jak też na społeczność euroregionalną. Potraktować je więc można z jednej strony, jako czynniki (narzędzia) oddziaływujące na pobudzanie przedsiębiorczości lokalnej, a z drugiej strony samo zaistnienie struktury euroregionalnej jest wyrazem nowej przedsiębiorczości w regionie. Warto więc wciąż badać euroregiony, które znacznie zmieniły swoje znaczenie. Do niedawna (szczególnie w Polsce, skromna literatura lat 90.) podawano, iż euroregiony służą do nawiązywania kontaktów po obu stronach granicy i to jest ich podstawowe zadanie. Euroregiony tworzą lobby, a ich siła oddziaływania nie jest wielka, ale będzie rosła.

2 Z. Przybyła, Euroregiony - nowy element narodowej i międzynarodowej polityki, w: B. Winiarski, Polityka gospodarcza, Wydawnictwo Naukowe PWN, Warszawa 2002, s. 562-567. 
Patrząc z perspektywy przeszło dwudziestu lat (pierwszy polski Euroregion Nysa utworzono w 1991 r.) trudno zgodzić się z tą argumentacją, chociaż była w niej optymistyczna zapowiedź rosnącej siły, która spełnia się na naszych oczach. Euroregiony przejęły działania kulturowe, ekologiczne, turystyczne i gospodarcze na peryferyjnych obszarach granic państwowych. Na typowo rolniczych obszarach przejęly funkcje wprowadzania wielofunkcyjnego rozwoju tychże terenów, eliminując bądź ograniczając takie czynniki hamujące rozwój wielofunkcyjny ${ }^{3}$, jak:

- brak środków finansowych,

- niedorozwój infrastruktury,

- brak niezbędnych instytucji,

- niski stan skolaryzacji,

- małe aspiracje ludności wiejskiej,

- brak odwagi w podejmowaniu ryzyka,

- mały stopień przedsiębiorczości.

Bliższą prezentację wpływu euroregionów na czynniki hamujące wielofunkcyjność polskiego rolnictwa w stosunku do doświadczeń europejskich zawiera tabela 1 .

Tabela 1

Euroregion a przezwyciężanie czynników hamujących wielofunkcyjny rozwój polskiej wsi i rolnictwa.

\begin{tabular}{|l|l|}
\hline \multicolumn{1}{|c|}{ Czynnik hamujący } & \multicolumn{1}{c|}{ Oddziaływanie euroregionalne } \\
\hline $\begin{array}{l}\text { Brak środków finanso- } \\
\text { wych }\end{array}$ & $\begin{array}{l}\text { Unijna pomoc strukturalna zarówno z polityki regionalnej, jak i rol- } \\
\text { nej oraz z ogólnych jak i przede wszystkim szczególnych progra- } \\
\text { mów operacyjnych (PO Polska Wschodnia, Europejska Współpraca } \\
\text { Terytorialna) oraz Inicjatyw Wspólnotowych przeznaczonych dla eu- } \\
\text { roregionów (w tym zarówno INTEREG, jak też LEADER) }\end{array}$ \\
\hline $\begin{array}{l}\text { Niedorozwój infrastruk- } \\
\text { tury }\end{array}$ & $\begin{array}{l}\text { Unijna pomoc strukturalna zarówno kierowana do regionów, jak też } \\
\text { przede wszystkim do euroregionów, w tym głównie w ramach PO } \\
\text { Infrastruktura i Środowisko }\end{array}$ \\
\hline Niski stopień solaryzacji & $\begin{array}{l}\text { Funkcją euroregionu jest rozwój społeczny oraz aktywizowanie lud- } \\
\text { ności euroregionalnej przez uruchamianie różnego rodzaju inicjatyw } \\
\text { np. szkolenia, doradztwo, wystawy, spotkania, czy nawet zakładanie } \\
\text { dwujęzycznych szkół, bądź współpracę tzw. nauczycieli wędrują- } \\
\text { cych (np. zachodnie polskie pogranicze) }\end{array}$ \\
\hline Małe aspiracje ludności & \begin{tabular}{l} 
Euroregion wzmaga poczucie więzi, tożsamości, dziedzictwa, prze- \\
\hline
\end{tabular}
\end{tabular}

3 E. Tomczak, Pomoc Unii Europejskiej w procesie przekształceń strukturalnych gospodarstw rolniczych, rozprawa doktorska, Politechnika Łódzka 2011, s. 192-201. 


\begin{tabular}{|l|l|}
\hline \multicolumn{1}{|c|}{ Czynnik hamujący } & \multicolumn{1}{c|}{ Oddziaływanie euroregionalne } \\
\hline wiejskiej & $\begin{array}{l}\text { lamuje wzajemne animozje i uprzedzenie, uświadamia poczucie wła- } \\
\text { snej wartości, co wynika z filozofii istnienia euroregionu }\end{array}$ \\
\hline $\begin{array}{l}\text { Brak odwagi w podej- } \\
\text { mowaniu ryzyka }\end{array}$ & $\begin{array}{l}\text { Euroregion wraz ze swym utworzeniem zbliżają ludność transgra- } \\
\text { niczną, niejako automatycznie wpaja w nią sens ponadgranicznego } \\
\text { współdziałania }\end{array}$ \\
\hline $\begin{array}{l}\text { Mały stopień przedsię- } \\
\text { biorczości }\end{array}$ & $\begin{array}{l}\text { Euroregion pobudza do wspólnego działania gdyż jest wyrazem } \\
\text { uświadomienia jedności i wspólnoty interesów przez granice pań- } \\
\text { stwowe, które zmienia z dzielących w czynnik jednoczący wysiłki } \\
\text { euroregionalnych mieszkańców. W ten sposób pobudza chéc i sens } \\
\text { do rozwijania przedsiębiorczości, która dalej mu uprzywilejowane } \\
\text { wsparcie w funduszowej pomocy strukturalnej }\end{array}$ \\
\hline
\end{tabular}

Źródło: opracowanie własne na podstawie: M. Greta, Transborder Cooperation, Euroregion and EU Regional Policy In the Context of Lisbon Strategy (Selected Examples of Polish Euroregions), Technical University of Lodz, Łódź 2008, s. 46 i dalsze.

Należałoby zauważyć, iż silne oddziaływanie na obszary zeuroregionalizowane zawdzięcza region swojemu zorganizowaniu przy pomocy instytucji (prezydium, sekretariat, tematyczne grupy robocze). W ten sposób staje się zwartą strukturą znaczącą w środowisku lokalnym. Znaczenie euroregionów na mapie Starego Kontynentu podnoszą również ich wspólne struktury organizacyjne lobbujące za nimi w Brukseli. W tym kontekście należałoby wspomnieć o Stowarzyszeniu Europejskich Regionów Granicznych (SERG).

SERG działa od początku lat 70. i ma siedzibę w Gronau (Niemcy). Celem stowarzyszenia jest m.in. rozpoznawanie problemów regionalnych, określanie ich szans i możliwości rozwojowych, a ponadto:

- reprezentowanie wspólnych problemów regionów granicznych, w tym szczególnie powiązanych w euroregiony wobec państw narodowych oraz na forum zjednoczonej Europy,

- inicjowanie, wzmacnianie i koordynowanie współpracy pomiędzy europejskimi regionami granicznymi i transgranicznymi, tworzenie i udoskonalanie sieci regionów granicznych,

- wymiana doświadczeń i informacji w celu wyodrębniania wspólnych interesów, koordynowania ich realizacji oraz rozwiązywania problemów z jakimi borykają się euroregiony ${ }^{4}$. (Greta 2013)

SERG realizuje powyższe cele poprzez:

4 M. Greta, Euroregiony polskie w procesie integracji europejskiej oraz w przezwyciężaniu peryferyjności i dysproporcji regionalnych, Wydawnictwo Uniwersytetu Łódzkiego, Łódź 2013. 
- wdrażanie programów i projektów oraz zdobywanie i zarządzanie odpowiednimi funduszami (SERG jest jednym $\mathrm{z}$ realizatorów programów unijnych),

- organizowanie imprez (konferencji, spotkań) poświęconych problemom regionów granicznych i trans granicznych,

- rozwijanie działalności Centrum Europejskich Regionów Granicznych i Transgranicznych i ścisłej współpracy z Unią Europejską oraz Radą Europy,

- informowanie opinii publicznej i środowisk politycznych o sprawach związanych z obszarami granicznymi,

- doradztwo dla regionów zrzeszonych w Stowarzyszeniu ${ }^{5}$. (Report The Committee of the Regions 2006)

Rozwój znaczenia SERG dla euroregionów powoduje, iż stowarzyszeniu przypisuje się „misję” specjalną o czym informuje tabela 2.

Tabela 2

„Misja specjalna” SERG.

\begin{tabular}{|l|l|}
\hline \multicolumn{1}{|c|}{ Misja SERG } & \multicolumn{1}{c|}{ Na czym polega dany rodzaj misji } \\
\hline SERG - Europa & - jedyna organizacja o zasięgu europejskim, reprezentująca regiony \\
& graniczne i trans graniczne \\
- & rzecznik polityczny wszystkich regionów granicznych i transgra- \\
& nicznych na poziomie europejskim \\
- & platforma europejska, napęd i punkt konsultacyjny w zakresie \\
& wszystkich aspektów współpracy transgranicznej
\end{tabular}

5 Report The Committee of the Regions and the Implementation and Monitoring of the Principles of Subsidiarity and Proportionality In teh Light of the Constitution for Europe, Committee of the Regions, Luxemburg, OOPEC 2006. 


\begin{tabular}{|l|c|}
\hline \multicolumn{1}{|c|}{ Misja SERG } & Na czym polega dany rodzaj misji \\
\hline $\begin{array}{l}\text { SERG - organizacja } \\
\text { niezastąpiona }\end{array}$ & $\begin{array}{l}- \text { dla wzmacniania dalszego rozwoju współpracy transgranicznej } \\
- \text { jako kluczowy element integracji europejskiej, przy zachowaniu } \\
\text { regionalnej różnorodności }\end{array}$ \\
\hline
\end{tabular}

Źródło: opracowanie własne na podstawie www.cor.eu.int; www.are_regions_europe_org; ale także wykorzystano Przewodnik LACE; M. Greta, Euroregiony polskie w procesie integracji europejskiej..., op.cit, s. 81 oraz Z. Przybyła, Wybrane kwestie realizacji wspótpracy transnarodowej na szczeblu lokalnym, w: Problemy rozwoju ekonomicznego pogranicza polsko-białoruskiego, Państwowy Uniwersytet im. J. Kupały w Grodnie, Grodno 2005 , s. $48-51$.

SERG odgrywa niezwykle istotną rolę, bowiem bez tej organizacji regiony transgraniczne, czy euroregiony, miałyby znacznie ograniczone możliwości zaistnienia na forum europejskim (SERG - Europa), praktycznie nie miałyby dostępu do informacji i wymiany doświadczeń (SERG - punkt serwisowy), nie byłyby przygotowane do tworzenia sieci współpracy ze swoimi ponadgranicznymi partnerami (SERG - sieci), a nadto SERG jest ważnym ogniwem integracji europejskiej (SERG - organizacja), gdyż to euroregiony umacniają integrację oraz często do niej prowadzą.

Duże doświadczenie SERG w zagadnieniach problemowych, a do takich należy rolnictwo i jego wielokierunkowe oddziaływanie na poszczególne euroregiony, które zrzeszone są w SERG, powoduje to, że euroregiony stają się skutecznym narzędziem oddziaływania na tereny, które obejmują swym wpływem. A zatem organizacja euroregionalna, jaką jest SERG, wpływa na dojrzałość, skuteczność, specjalizację euroregionu, a ten oddziałuje na obszary będące w składzie euroregionu.

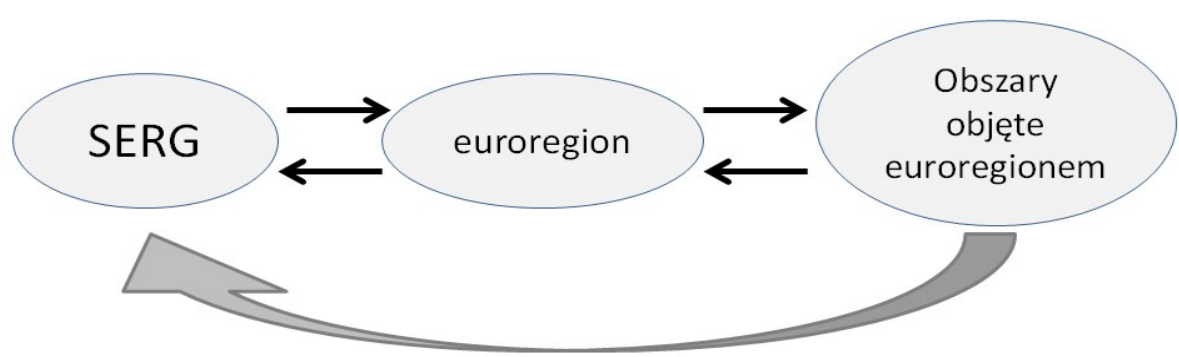

Rys. 2. Interakcje euroregionu i jego wyższych struktur instytucjonalnych

Źródło: opracowanie własne na podstawie wiedzy własnej o prezentowanych zagadnieniach. 
$\mathrm{Na}$ rysunku zaprezentowano interakcje jakie zachodzą między euroregionem a jego instytucjonalizacją, dzięki której SERG jest poinformowany o lokalnych problemach euroregionów, a dalej może je także reprezentować na forum Unii Europejskiej.

Skuteczność oddziaływania samych euroregionów, do czego dochodzi jeszcze szczególne poparcie ze strony ich pomysłodawców, czyli Niemiec, powoduje, iż euroregiony są uprzywilejowanymi regionami w UE. Przejawia się to na różne sposoby, ale m.in. w pomocy strukturalnej. W związku z powyższym, w dalszej części opracowania zwrócono uwagę na niektóre aspekty z tym związane, tj. wybrane inicjatywy wspólnotowe, a głównie INTEREG A oraz LEADER.

\section{Inicjatywy Wspólnotowe w aspekcie rolnictwa wielofunkcyjne- go}

Inicjatywy Wspólnotowe mają w Unii Europejskiej stałe miejsce i historię jako środki finansowe powoływane do realizacji zadań trudnych i obsługiwania regionów problemowych ${ }^{6}$ (Tomczak, Kaźmierska 2009). Ich przegląd dowodzi, iż trafiały one dość często na tereny rolnicze właśnie przez euroregion i oddziaływały na wyeksponowanie jego rolniczych, endogenicznych możliwości rozwojowych o charakterze wielofunkcyjności. W tym miejscu warto by zaprezentować, te które najbardziej „przysłużyły się” rolnictwu, tj. INTERREG A oraz LEADER. Informacje o nich zawarto w tabeli 3.

Tabela 3

Zasięg geograficzny i tematyczny INTEREG A oraz LEADER.

\begin{tabular}{|l|r|}
\hline \multicolumn{1}{|c|}{ Zasięg geograficzny } & Zasięg tematyczny \\
\hline Wszystkie obszary & - promocja regionów przybrzeżnych, wiejskich i miejskich dotycząca \\
przygraniczne wzdłuż & m. in.: tworzenia planów zagospodarowania przygranicznych obsza- \\
wewnętrznych i ze- & rów, ochrony obszarów leśnych jak i całego środowiska, promocja \\
wnętrznych granic & aktywności gospodarczej na obszarach wiejskich \\
UE w tym przede & - wspomaganie rozwoju przedsiębiorczości i małych firm dotyczące \\
\hline
\end{tabular}

6 E. Tomczak, A. Kaźmierska, The European Commission as a Representative of the Common Values of the Member Countries of the European Union, w: Socio-Economic Aspects of the European Union, red. M. Greta, M. Sekieta, R. Stanisławski, Technical University of Lodz, Łódź 2009. 
Marianna Greta, Ewa Tomczak-Woźniak: Wplyw euroregionalizacji na...

\begin{tabular}{|c|c|}
\hline Zasięg geograficzny & Zasięg tematyczny \\
\hline $\begin{array}{l}\text { wszystkim obszary } \\
\text { objęte euroregionami }\end{array}$ & $\begin{array}{l}\text { m. in.: tworzenia programów doradczych i inwestycyjnych dla sekto- } \\
\text { ra MSP, wprowadzania nowych produktów turystycznych } \\
\text { - promocja integracji rynku pracy i integracji społecznej dotycząca m. } \\
\text { in.: działań na rzecz wdrażania paktów odnośnie zatrudnienia, mają- } \\
\text { cych na celu społeczną integrację } \\
\text { - współpraca odnoście rozwoju technologicznego, kultury, edukacji, } \\
\text { zdrowia, badań naukowych, skutkującej np. tworzeniem nowych } \\
\text { miejsc pracy } \\
\text { - ochrona środowiska dotycząca m.in. działań monitoringowych, pre- } \\
\text { wencyjnych, promocyjnych w zakresie korzystania z alternatywnych } \\
\text { źródeł energii } \\
\text { - podstawowa infrastruktura dotycząca m.in.: poprawy więzi między } \\
\text { przygranicznymi regionami } \\
\text { - współpraca obejmujące dziedzinę prawa i administracji dotycząca } \\
\text { m.in.: projektów pilotażowych, studio szkolenia personelu granicz- } \\
\text { nego, ograniczenia problemów w funkcjonowaniu jednolitego rynku } \\
\text { po obu stronach granicy } \\
\text { - współpraca między instytucjami i obywatelami dotycząca m.in.: } \\
\text { szkoleń językowych, finansowania przedsięwzięć mających na celu } \\
\text { integracje mieszkańców }\end{array}$ \\
\hline $\begin{array}{l}\text { Obszary typowo rol- } \\
\text { nicze państw człon- } \\
\text { kowskich UE, tak re- } \\
\text { giony wewnętrzne, } \\
\text { jak i na granicach, } \\
\text { w tym przede wszyst- } \\
\text { kim euroregiony }\end{array}$ & $\begin{array}{l}\text { - strategie dotyczące rozwoju obszarów wiejskich. Obszar wiejski, } \\
\text { który zakwalifikował się do wsparcia musiał być jednorodny pod } \\
\text { względem społecznym, ekonomicznym i geograficznym oraz musiał } \\
\text { być zamieszkały przez co najmniej } 10 \text { tys. osób, ale nie więcej niż } \\
100 \text { tys. osób. Strategie musiały dotyczyć chociaż jednego z tematów } \\
\text { znajdujących się w wytycznych do programów ustanowionych przez } \\
\text { Komisję Europejską. Musiały mieć również charakter pilotażowy } \\
\text { i tym samym wprowadzać nowe rozwiązania dla problemów wystę- } \\
\text { pujących na obszarze. Tematy wymienione w wytycznych dotyczyły } \\
\text { np.: konkurencyjności produktów na obszarze wiejskim, dostępu do } \\
\text { nowych technologii, wykorzystania know-how, wykorzystania zaso- } \\
\text { bów naturalnych } \\
\text { - współpraca pomiędzy obszarami wiejskimi. Współpraca odbywała } \\
\text { się na poziomie jednego kraju i na poziomie ponadnarodowym i po- } \\
\text { legała na wymianie know-how oraz wdrażaniu projektów opracowy- } \\
\text { wanych przez lokalne grupy zadaniowe } \\
\text { - sieciowanie. Sieciowanie wiązało się z wymianą doświadczeń, prak- } \\
\text { tyk i wiedzy na terenach wiejskich bez względu na realizację dwóch } \\
\text { poprzednich działań }\end{array}$ \\
\hline
\end{tabular}

Źródło: opracowanie własne na podstawie: http://epp.eurostat.ec.europa.eu; http://ec.europa.eu/ regional_policy/urban2/pdf/URBAN12_a3_final_3c.pdf oraz M. Greta, Euroregiony polskie w procesie integracji europejskiej..., s. $8 \overline{1}$.

Inicjatywa INTERREG zwłaszcza w komponencie A jest kierowana do euroregionów, a w swym zasięgu tematycznym, albo bezpośrednio wspiera rolnictwo w jego przedsiębiorczym wymiarze, albo pośrednio promując rozwój różnych form infrastruktury gospodarczej, społecznej czy też transportowej, dzia- 
łania edukacyjne, kulturowe itp. INTERREG A ma wyłącznie transgraniczny charakter, gdzie przeważają obszary wiejskie ${ }^{7}$.

Inicjatywa LEADER to $\mathrm{w}$ założeniu swym inicjatywa typowo rolno-przedsiębiorcza, a stawiane wymogi terytorialne powodują, iż zaznacza swą aktywność w euroregionach. Tym samym to euroregion oddziałuje na pobudzanie aktywności wielofunkcyjnej na wsi. Inicjatywa LEADER wspomaga realizację osi Programu Rozwoju Obszarów Wiejskich (PROW) przyjętych i realizowanych w perspektywie finansowej 2007-2013 (także aktualnie, bo realizacja tej perspektywy trwa do 2015 r.) Tak więc wspomaga:

- poprawę konkurencyjności sektora rolnego i leśnego,

- poprawę środowiska naturalnego i obszarów wiejskich,

- jakość życia na obszarach wiejskich oraz zróżnicowanie działalności gospodarczej,

- oś LEADER.

Czwarta oś LEADER (którą aktywnie wspiera Inicjatywa Wspólnotowa o tej nazwie) jest podejściem praktycznym, przyczyniającym się do aktywizacji wiejskich społeczności m.in. przez włączenie partnerów gospodarczych i społecznych do planowania i wdrażania lokalnych inicjatyw mających swój odzew m.in. w Lokalnych Grupach Działania (LGD). Podstawą funkcjonowania i aktywności LGD jest opracowanie Lokalnych Strategii Rozwoju (LSR) i realizacja wynikających z nich działań innowacyjnych łączących zasoby ludzkie, naturalne, kulturowe, historyczne oraz wiedzę i umiejętności przedstawicieli z różnych sektorów gospodarowania. LGD są obecne w polskich euroregionach i skutecznie oddziałują na aktywizację obszarów wiejskich, zwłaszcza dotyczy to naszego wschodniego pogranicza.

\section{Podsumowanie}

Wielofunkcyjność na stałe wpisała się w mapę rozwojową rolnictwa zjednoczonej europy, która rozwija się uwzględniając wymogi Wspólnej Polityki Rolnej (WPR), która dziś przybrała już postać Wspólnej Polityki Rozwoju Wsi i Obszarów Wiejskich (WPRWiOW), co też wskazuje na jej strukturalny wy-

7 M. Greta, Institutional, Legal and Financial Aspects of the Functioning of Euroregions and Their Activity in the Youngest Polish Euroregions as well as in the Oldest One: Bialowieza Forest, Szeszupa, Lyna-Lava and Neisse, Technical University of Lodz, Łódź 2011, s. 55 i dalsze. 
miar. Na słuszność i szanse dla rolnictwa jako wielofunkcyjnego wskazują też stawiane po 2013 roku wyzwania, jak m.in.:

- zapewnienie bezpieczeństwa żywnościowego i wysokiej jakości produktów,

- stosowanie wysokich norm ochrony środowiska naturalnego,

- konieczność tworzenia nowych miejsc pracy,

- wykorzystanie źródeł odnawialnych.

Powyższe spostrzeżenia dotyczą również polskiego rolnictwa. Jednym $\mathrm{z}$ aspektów oddziaływania na polskie rolnictwo w kierunku pobudzania jego wielofunkcyjności, w rozumieniu współczesnym i integracyjnym, są euroregiony oraz Inicjatywy Wspólnotowe trafiające do euroregionalnych obszarów wiejskich. Rozważania pozwoliły autorom na stwierdzenie, iż konstrukcja, założenia i podjęte działania euroregionalne walnie przyczyniają się do stymulowania przedsiębiorczości lokalnej, w tym przede wszystkim na obszarach wiejskich. Ponadto już sama obecność struktur euroregionalnych na obszarach wiejskich stanowi nową formę przedsiębiorczości, nad którą patronuje SERG. Pomimo przyjętych norm publikacyjnych, w celu syntetycznego podsumowania wyników rozważań, autorzy pozwolili sobie na zamieszczenie w tym miejscu samodzielnie przygotowanego schematu.

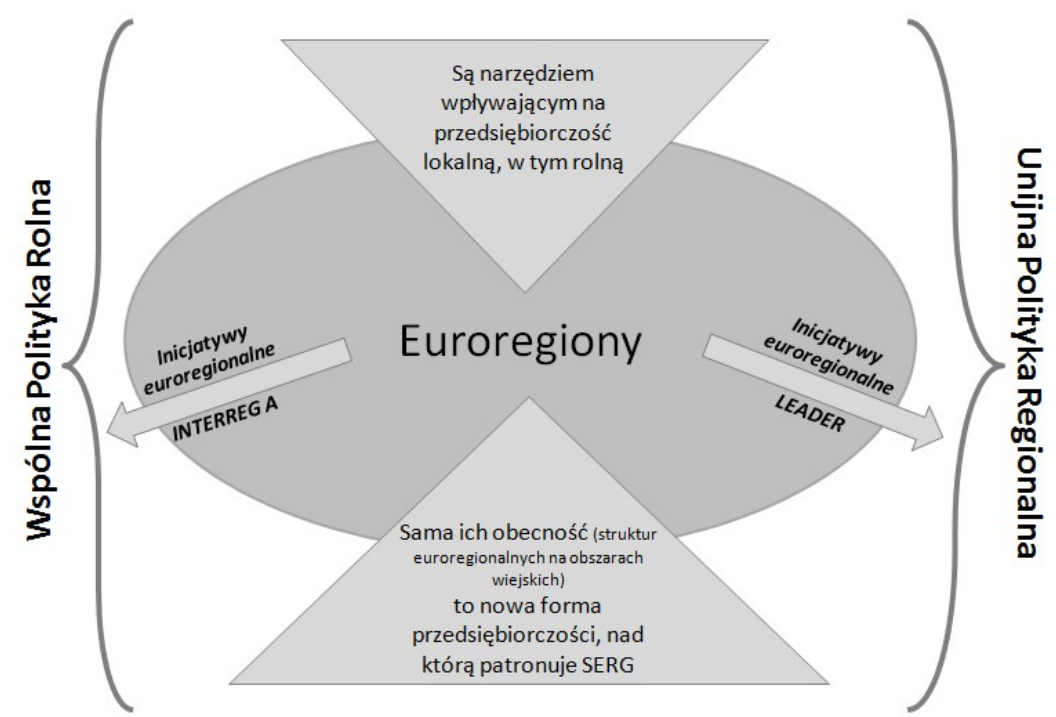

Rys. 3. Euroregion a wielofunkcyjność wiejska

Źródło: opracowanie własne na podstawie wiedzy własnej o prezentowanych zagadnieniach. 


\section{Literatura}

Greta M., Euroregiony polskie w procesie integracji europejskiej oraz w przezwyciężaniu peryferyjności $i$ dysproporcji regionalnych, Wydawnictwo Uniwersytetu Łódzkiego, Łódź 2013.

Greta M., Institutional, Legal and Financial Aspects of the Functioning of Euroregions and Their Activity in the Youngest Polish Euroregions as well as in the Oldest One: Bialowieza Forest, Szeszupa, Lyna-Lava and Neisse, Technical University of Lodz, Łódź 2011.

Greta M., Transborder Cooperation, Euroregion and EU Regional Policy In the Context of Lisbon Strategy (Selected Examples of Polish Euroregions), Technical University of Lodz, Łódź 2008.

Halamska M., Transformacja wsi 1989-2009: zmienny rytm modernizacji, „Studia Regionalne i Lokalne" 2011, nr 2 (44).

http://ec.europa.eu/regional_policy/urban2/pdf/URBAN12_a3_final_3c.pdf.

http://epp.eurostat.ec.europa.eu.

Przybyła Z., Euroregiony - nowy element narodowej i międzynarodowej polityki, w: B. Winiarski, Polityka gospodarcza, Wydawnictwo Naukowe PWN, Warszawa 2002.

Przybyła Z., Wybrane kwestie realizacji wspótpracy transnarodowej na szczeblu lokalnym, w: Problemy rozwoju ekonomicznego pogranicza polsko-białoruskiego, Państwowy Uniwersytet im. J. Kupały w Grodnie, Grodno 2005.

Radwan A., Paluch Ł., Zróżnicowanie infrastruktury i jakości środowiska naturalnego regionów wschodniej Polski, w: K. Michałowski, Wplyw roli zrównoważonego rozwoju na politykę państwa i regionu, t. 2, „Problemy Regionalne i Lokalne”. Wydawnictwo WSE w Białymstoku, Białystok 2009.

Report The Committee of the Regions and the Implementation and Monitoring of the Principles of Subsidiarity and Proportionality In teh Light of the Constitution for Europe, Committee of the Regions, Luxemburg, OOPEC 2006.

Tomczak E., Kaźmierska A., The European Commission as a Representative of the Common Values of the Member Countries of the European Union, w: SocioEconomic Aspects of the European Union, red. M. Greta, M. Sekieta, R. Stanisławski, Technical University of Lodz, Łódź 2009.

Tomczak E., Pomoc Unii Europejskiej w procesie przekształceń strukturalnych gospodarstw rolniczych, rozprawa doktorska, Politechnika Łódzka, Łódź 2011, [niepublikowana]. 


\title{
The influence of the euroregionalization on deagrarianization of villages and farmings
}

\begin{abstract}
Summary
The article according to the purpose is presenting the attempt of grabbing hold of the influence of the euroregionalization on the multifunctionality of the village and farmings. That influence was presented taking into consideration of determinants of the multifunctionality including Euroregion, which is heightening their influences, and is eliminating negative effects in this regard. It is direct influence of the Euroregion on deagrarianization. It should also be noticed that it $i$ salso an indirect influence described here using the institution to the euroregional (SERG) and of Community Initiatives (INTERREG A and LEADER). Deliberations allowed to state, that Euroregions, using a wide range of the instrumentation of the regional policy and community initiatives, are a tool stimulating the local entrepreneurship including agricultural entrepreneurship. From the other side already the presence of euroregional structures is a new form of the entrepreneurship in country areas.
\end{abstract}

Keywords: de-agrarianization, farming, regional policy, Euroregion.

Translated by Marianna Greta and Ewa Tomczak-Woźniak 